
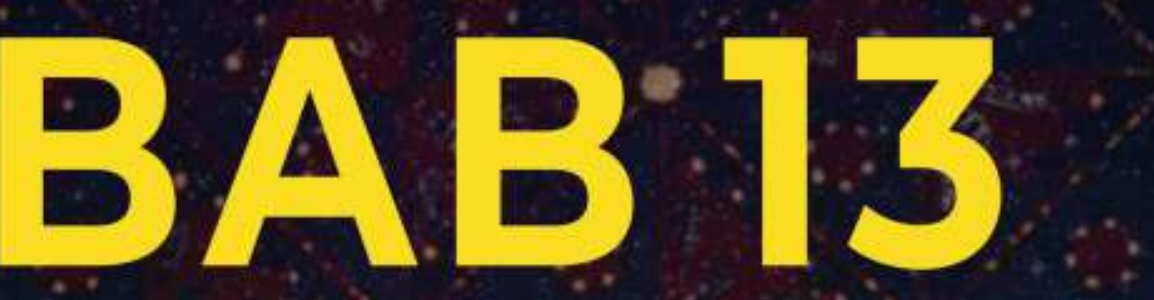

APLIKASI ANALISIS KERUANGAN
DALAM KEBIJAKAN MENGHADAPI
COVID-19 DI INDONESIA
$\therefore$ 


\title{
BAB 13
}

\section{APLIKASI ANALISIS KERUANGAN DALAM KEBIJAKAN MENGHADAPI COVID-19 DI INDONESIA}

\author{
Mohammad Isnaini Sadali ${ }^{1}$, Ersa Latifa Rosewidiadari ${ }^{1}$
}

\begin{abstract}
Afiliasi dan korespondensi
${ }^{1}$ Departemen Geografi Pembangunan, Fakultas Geografi, UGM m.isnaini.s@ugm.ac.id.
\end{abstract}

\begin{abstract}
ABSTRAK
COVID-19 dinyatakan sebagai pandemi dan kedaruratan kesehatan masyarakat yang meresahkan dunia, oleh karena itu diperlukan perhatian dan peran serta berbagai keilmuan untuk mencari solusi dalam menghadapinya. Salah satu pendekatan geografi yang dapat dimanfaatkan untuk mendukung pengambilan keputusan (kebijakan) adalah pendekatan keruangan. Analisis lokasi, persebaran/distribusi keruangan, dan prediksi/trend terhadap kasus COVID-19 dapat dilakukan dengan analisis keruangan dan diintegrasikan dengan analisis lain guna mendapatkan hasil yang diharapkan. Tujuan dari tulisan ini adalah menganalisis beberapa kebijakan pemerintah di Indonesia yang menggunakan analisis keruangan untuk menghadapi COVID-19. Metode yang digunakan adalah analisis deskriptif kuantitatif, dengan data sekunder sebagai sumber data utama. Hasil kajian menunjukkan bahwa analisis keruangan telah dimanfaatkan pemerintah sebagai bahan dan bagian dalam pengambilan kebijakan. Beberapa kebijakan di Indonesia yang menggunakan analisis keruangan adalah analisis lokasi dan sebaran kasus COVID-19, serta analisis area (wilayah) terdampak atau beresiko. Analisis keruangan dapat dimanfaatkan untuk mendukung sebuah kebijakan maupun keputusan, sehingga tindakan antisipasi penyebaran dan pencegahan kasus COVID-19 dapat dilakukan lebih awal.
\end{abstract}

Kata kunci: Analisis keruangan, COVID-19, kebijakan, pembangunan wilayah.

\section{A. Konteks dan Masalah \\ Latar Belakang}

Permasalahan COVID-19 yang terjadi di Indonesia saat ini bukan hanya merupakan permasalahan di bidang kesehatan, meskipun memang COVID-19 ini menjadi perhatian kesehatan dunia. Hal ini ditunjukkan dengan dinyatakannya COVID-19 sebagai Kedaruratan Kesehatan Masyarakat yang Meresahkan Dunia 
atau Public Health Emergency of International Concern (PHEIC) dan dinyatakan sebagai pandemi sejak tanggal 11 Maret 2020 oleh WHO (Kementerian Kesehatan, 2020). Penyebaran virus yang cepat dan terus meluas ke seluruh bagian dunia ini menyerang manusia sebagai host (inang) untuk bertahan pada salah satu sel dalam tubuh manusia. Sejak pertama kali dilaporkan kasus pneumonia di Kota Wuhan-China (31 Desember 2019), WHO mengkonfirmasi terdapat 11.84.226 kasus dengan 545.481 kematian di seluruh dunia (Case Fatality Rate/CFR 4,6\%) pada 9 Juli 2020. Sedangkan di Indonesia Kementerian Kesehatan melaporkan dari kasus pertama (pada tanggal 2 Maret 2020) terus meningkat dan menyebar dengan cepat di seluruh daerah Indonesia dengan 70.736 kasus konfirmasi COVID-19 dan 3.417 kasus meninggal (CFR 4,8\%) hingga tanggal 9 Juli 2020. Angka kematian akibat COVID-19 di Indonesia yang tinggi (di atas rata-rata angka kematian dunia), maka Pemerintah Indonesia menetapkan Kedaruratan Kesehatan Masyarakat Corona Virus Disease 2019 (COVID-19) melalui Keputusan Presiden Nomor 11 Tahun 2020.

Mengingat pentingnya informasi dan data yang valid (terpercaya), maka Kementerian Kesehatan Republik Indonesia mengeluarkan COVID-19 dalam Angka. Berdasarkan data COVID-19 dalam Angka tersebut, diketahui bahwa tren kasus COVID-19 di Indonesia terus meningkat. Hingga 15 Agustus 2020 tren peningkatan kasus masih berbentuk kurva esponensial dengan jumlah kasus terkonfirmasi 137.468 kasus dalam rentang waktu 167 hari (lihat). Dengan kata lain rata-rata pertumbuhan kasus terkonfirmasi COVID-19 di Indonesia sebesar $0,21 \%$.

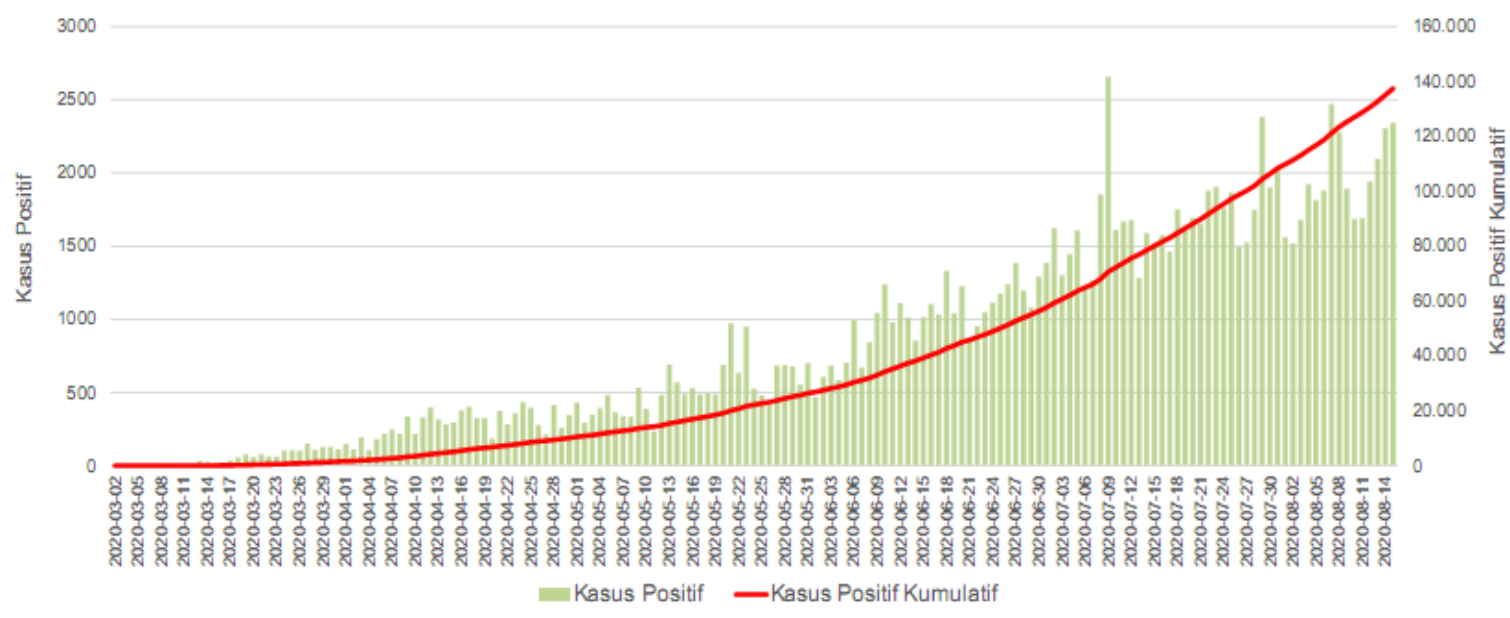

Gambar 13.1 Tren Kasus Harian COVID-19 di Indonesia Sumber: Kementerian Kesehatan RI (COVID-19 dalam Angka, kondisi 15 Agustus 2020) 
Kasus COVID-19 memiliki hubungan erat dengan bidang kesehatan, akan tetapi kajian mengenai COVID-19 perlu dilakukan oleh berbagai bidang keilmuan karena dampaknya yang sangat luas dan menimbulkan perubahan hampir di seluruh aspek kehidupan (politik, ekonomi, sosial, budaya, pertahanan dan keamanan, maupun kesejahteraan masayarakat). Potensi meluasnya penyebaran COVID-19 selalu dikaitkan dengan mobilitas penduduk (Merler \& Ajelli, 2012; Kementerian Kesehatan, 2020). Virus ini menyebar secara contagious yang menyebar secara cepat dalam sebuah jaringan (Mona, 2020), dalam hal ini wabah atau penyakit yang menginfeksi inangnya untuk bertahan. Hingga saat ini obat maupun vaksin untuk melawan COVID-19 masih dalam proses pengujian, meskipun di beberapa negara sudah ada yang menguji bahkan memberikan vaksin untuk melawan COVID-19 secara massal. Upaya memutus rantai penyebaran COVID-19 di Indonesia dan beberapa negara lain dilakukan dengan berbagai istilah seperti lockdown, isolasi total, karantina, dan lain-lain.

Di Indonesia istilah formal yang digunakan daerah sebagai kebijakan melakukan pembatasan kegiatan atau pergerakan manusia adalah Pembatasan Sosial Berskala Besar (PSBB). Beberapa turunan kebijakan untuk memutus rantai penyebaran COVID-19 di Indonesia yang harus dilakukan daerah maupun individu diantaranya: tetap di rumah, isolasi diri, pembatasan transportasi dan akses fasilitas publik, serta physical distancing. Kebijakan-kebijakan ini berhubungan dengan analisis keruangan terutama proses difusi keruangan atau penyebaran COVID-19 di Indonesia. Melalui pendekatan keruangan, kasus COVID-19 dapat diketahui lokasi dan distribusinya, lebih jauh lagi analisis keruangan dapat diintegrasikan dan diaplikasikan untuk analisis yang lebih kompleks, misalnya untuk analisis prediksi atau tren. Dengan demikian aplikasi analisis keruangan untuk penanganan dan penanggulangan permasalahan COVID-19 dapat menjadi pendukung pemangku kebijakan dalam merumuskan strategi dan arah kebijakan pada level global hingga regional.

\section{Tujuan}

Tulisan ini merupakan bentuk kajian yang mengintegrasikan antara konsep dan terapannya (emipirs) pada situasi atau masa pandemi COVID-19 yang terjadi di Indonesia. Teori dan konsep pendekatan dalam geografi (pendekatan keruangan) dikaji relevansinya terkait kondisi yang berkembang saat ini, dengan telaah beberapa kebijakan yang dikeluarkan Pemerintah Indonesia dalam menghadapi pendemi COVID-19. Tujuan dari tulisan ini untuk mengkaji beberapa kebijakan pemerintah di Indonesia yang menggunakan atau 
Aplikasi Analisis Keruangan dalam Kebijakan Menghadapi Covid-19 di Indonesia

memanfaatkan analisis keruangan untuk pencegahan dan penanggulangan COVID-19.

\section{Metode}

Pendekatan deduktif digunakan dalam kajian ini untuk melihat teori dan konsep dari analisis keruangan yang diaplikasikan pada kondisi nyata atau yang terjadi saat ini (empiris), khususnya konsep dan teori yang diterapkan dalam kebijakan-kebijakan menghadapi COVID-19 di Indonesia. Kajian ini menggunakan metode analisis diskriptif kuantitatif untuk mengetahui dan menjelaskan kebijakan-kebijakan di Indonesia yang didukung oleh analisis keruangan. Data yang digunakan adalah data sekunder yang sebagian besar merupakan data publikasi Pemerintah Republik Indonesia melalui laman https://covid19.go.id/. Lingkup wilayah kajian dalam tulisan ini adalah Negara Indonesia dengan mengambil beberapa daerah sebagai contoh dari sampel kasus.

\section{B. Tinjauan Aspek Teori dan Konsep}

Analisis keruangan merupakan bagian dari kajian ilmu geografi yang dapat dimanfaatkan sebagai bahan pertimbangan dalam pengambilan kebijakan menghadapi pendemi COVID-19 yang sedang melanda Indonesia. Kajian ilmu geografi memiliki 3 (tiga) pendekatan: yaitu pendekatan keruangan, pendekatan ekologi, dan pendekatan kompleks wilayah (Bintarto \& Hadisumarno, 1979). Pendekatan keruangan menekankan pada analisa sintesis terhadap variasi perbedaan lokasi di permukaan bumi serta faktor-faktor apa yang dominan mempengaruhi perbedaan tersebut. Pendekatan ekologi mengkaji interaksi makhluk hidup (manusia, hewan, tumbuhan) dengan lingkungan (alam). Pendekatan kompleks wilayah merupakan gabungan dari pendekatan keruangan dan pendekatan ekologi yang menekankan pada kajian yang lebih komprehensif suatu wilayah yang di dalamnya terdapat aspek fisik dan manusia (Aksa, Utaya, \& Bachri, 2019).

Kajian geografi dalam analisis keruangan berkaitan dengan data lokasi yang berupa titik (point) dan area (bidang). Perbedaan lokasi di permukaan bumi dapat dianalisis dengan melihat sebaran ruang, penggunaan/pemanfaatan ruang, relasi dan integrasi ruang, serta sistem keruangan (Bintarto \& Hadisumarno, 1979; Haggett, 1983; Sumaatmadja, 1988). Ruang dalam konteks wilayah dapat dikembangkan analisis lebih luas berkaitan dengan pewilayahan (regionalization), klasifikasi (classification), ramalan wilayah (regional forecasting), dan perencanaan wilayah (regional planning). Jenis analisis keruangan yang populer meliputi tata keruangan (spatial arrangement), difusi 
Aplikasi Analisis Keruangan dalam Kebijakan Menghadapi Covid-19 di Indonesia

keruangan (spatial diffusion), interaksi keruangan (spatial interaction), dan alokasi keruangan (spatial allocation) (Bintarto \& Hadisumarno, 1979; Haggett, 1983).

Analisis tata keruangan mempelajari perbedaan lokasi dengan penekanan pada persebaran pemanfaatan ruang dan ketersediaan ruang. Di Indonesia salah satu bentuk formal aplikasi analisis ini diatur dalam Undang-Undang (UU) Nomor 26 Tahun 2007 tentang Penataan Ruang yang meliputi perencanaan tata ruang, pemanfaatan ruang, dan pengendalian pemanfaatan ruang. Difusi keruangan merupakan penjalaran, penyebaran, pemencaran informasi maupun material dari lokasi satu ke lokasi lainnya. Terdapat 3 difusi keruangan dalam pendekatan geografi, yaitu expansion diffusion, relocation diffusion, dan association diffusion. Interaksi keruangan menurut Edward Ullman dapat terjadi apabila ada complemetary (perbedaan demand and supply antar wilayah), intervening opportunity (peluang atau daya tarik wilayah), dan transferability (faktor jarak, waktu, dan biaya) (Suharyono \& Amien, 1994). Sedangkan alokasi keruangan berkaitan dengan optimalisasi sumberdaya melalui penentuan lokasi yang paling sesuai.

Berkaitan dengan kasus pandemi COVID-19, terjadi proses penyebaran baik melalui manusia maupun media lain sebagai perantara dan melintasi ruang/wilayah tertentu. Fenomena tersebut dalam analisis keruangan termasuk dalam bentuk difusi keruangan yang hingga saat ini kecenderungannya masih berkembang/menyebar semakin besar ke wilayah yang lebih luas (difusi ekspansi). Penyebaran COVID-19 di Indonesia menurut (Mona, 2020) terjadi secara contagious, dimana proses difusi berlangsung menjalar seperti sebuah jaringan yang saling terhubung. Hubungan ini ditunjukkan dengan adanya keterkaitan antara kasus COVID-19 yang terjadi sebelumnya dengan kasus yang lain. Menurut Newman dalam (Mona, 2020), salah satu alasan utama mempelajari jaringan (termasuk proses contagion di dalamnya) adalah untuk memahami mekanisme di mana penyakit maupun informasi, virus komputer, rumor, menyebar di dalamnya. Dengan demikian kasus pandemi COVID-19 yang terjadi di Indonesia maupun dunia merupakan proses difusi keruangan yang menyebar melalui mobilitas/pergerakan manusia maupun material tertentu sebagai perantara.

Pemanfaatan analisis keruangan untuk mendukung pengambilan keputusan dalam menghadapi COVID-19 meliputi analisis lokasi baik berupa analisis titik lokasi (point) untuk melihat sebaran lokasi kasus COVID-19 dan analisis area (wilayah) terdampak oleh COVID-19. Analisis aera terdampak COVID-19 salah satunya dengan regionalisasi. Regionalisasi sering dikenal juga 
sebagai proses pewilayahan, yaitu mengelompokkan atau mengklasifikasikan unsur-unsur yang sama. Menentukan pewilayahan atau regionalisasi suatu wilayah di permukaan bumi, dipergunakan kriteria geografi hasil relasi keruangan aspek-aspek yang secara umum lebih menonjol atau lebih dominan pada wilayah yang bersangkutan (Sumaatmadja, 1988). Aplikasi regionalisasi yang dilakukan di Indonesia merujuk pada pewilayahan secara formal, dengan batas pewilayahan berdasarkan pada batas administrasi pemerintahan. Output dari regionalisasi pada kasus COVID-19 di Indonesia adalah zonasi wilayah resiko terdampak COVID19.

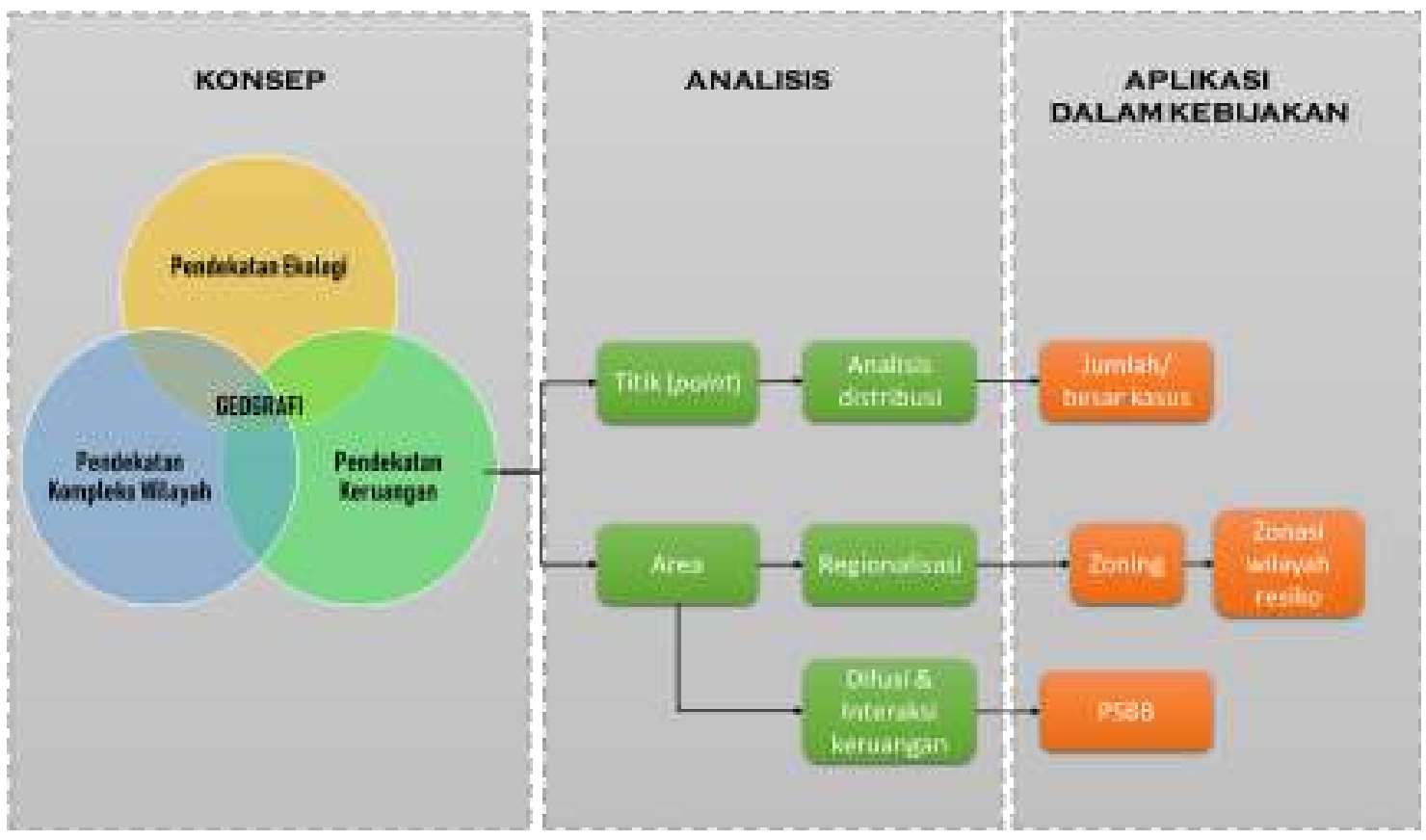

Gambar 13.2 Kerangka Teori

\section{Hasil dan Pembahasan}

Pandemi COVID-19 mengakibatkan suatu krisis global yang sangat meresahkan dunia. Virus korona jenis baru ini, berhasil menggemparkan dunia dan saat ini telah menyebar ke lebih dari 200 negara di dunia, tak terkecuali Indonesia. Di Indonesia sendiri, kasus pertama munculnya COVID-19 terjadi pada bulan Maret 2020 dengan kasus yang kian meningkat hingga saat ini (Kementerian Kesehatan, 2020). Hal ini dikarenakan penyebaran dan penularan virus berlangsung sangat cepat. Secara umum kecepatan penularan virus ini bergantung pada 2 (dua) hal, yaitu banyaknya orang yang terinfeksi dari satu kasus dan lamanya infeksi antarorang. Infeksi antarorang dapat terjadi melalui droplet atau cipratan dari hidung maupun mulut terinfeksi sehingga saran pencegahan penyebaran yang dapat dilakukan adalah dengan menggunakan 
Aplikasi Analisis Keruangan dalam Kebijakan Menghadapi Covid-19 di Indonesia

masker dan menjaga jarak antarorang, terlebih saat aktivitas tertentu yang mengharuskan untuk berinteraksi langsung dengan orang lain.

Secara astronomis Indonesia terletak di garis khatulistiwa dan sekitarnya, sehingga Indonesia memiliki iklim tropis yang paparan sinar matahari hariannya tergolong tinggi dan begitu pula temperatur hariannya. Kondisi fisik ini menyuguhkan keuntungan bagi Indonesia semasa pandemi COVID-19 dibandingkan dengan negara lain yang memiliki temperatur rendah. Terdapat keterkaitan antara penyebaran COVID-19 dengan kondisi iklim dan cuaca di suatu wilayah. Berdasarkan hasil analisis (Islam, Shabnam, \& Erzurumluoglu, 2020) serta (Araujo \& Naimi, 2020) menunjukkan bahwa tingkat kerentanan penyebaran COVID-19 pada negara dengan iklim tropis lebih rendah daripada negara dengan lintang tinggi. Hal ini berarti Indonesia diuntungkan oleh letak geografisnya. Kondisi menguntungkan ini tak semerta mengecualikan Indonesia dalam penyebaran pandemi COVID-19. Kasus infeksi COVID-19 nyatanya telah menyebar ke penjuru negeri. Berdasarkan data Gugus Tugas Percepatan Penanganan COVID-19 per 10 April 2020, pandemi COVID-19 telah menyebar di seluruh provinsi Indonesia atau dengan kata lain total sebanyak 34 provinsi di Indonesia telah terpapar COVID-19 dengan angka yang bervariasi.

Penelitian (Chen, et al., 2020) dan (Luiseto, et al., 2020) menyatakan bahwa terdapat klasifikasi wilayah rentan penyebaran COVID-19 yaitu wilayah dengan temperatur sekitar $8-10^{\circ} \mathrm{C}$ dan kelembapan sekitar 60-90\%. Daerahdaerah di Indonesia sendiri memiliki rata-rata temperatur sekitar $27-33^{\circ} \mathrm{C}$ dan kelembapan sekitar 70-90\%. Makin tinggi temperatur suatu wilayah, makin rendah kemungkinan kasus positif hariannya. Tinggi rendahnya temperatur wilayah berpengaruh pula dengan ketinggian tempat suatu wilayah. Hal ini sejalan dengan hasil tinjauan data epidemiologi dari kasus Bolivia, Ekuador, dan Tibet melalui penelitian gabungan Australia, Bolivia, Kanada, dan Swiss dalam jurnal Respiratory Physiology \& Neurobiology yang menyimpulkan bahwa di Tibet terdapat tingkat infeksi COVID-19 yang sangat jauh lebih rendah dibandingkan dengan Cina, dan tiga kali lebih rendah dari Andes Bolivia, serta empat kali lebih rendah dari Andes Ekuador. Hasil tersebut didapatkan berdasarkan titik ketinggian wilayah, yaitu semakin tinggi titik ketinggian wilayah, semakin rendah resiko terinfeksi COVID-19, atau dengan kata lain penduduk di dataran tinggi dengan temperatur rendah memiliki kerentanan lebih rendah terinfeksi COVID-19 daripada penduduk yang tinggal di dataran rendah. Analisis keruangan yang telah dilakukan para peneliti di atas tidak terlepas dari kajian geografi dengan wilayah sebagai obyek formalnya. 
Tiap region (wilayah) di Indonesia memiliki ciri khas kehidupan tertentu yang menyuguhkan suatu keseragaman tertentu dengan pendekatan keruangan. Region yang ditentukan berdasarkan kesamaan gejala internal disebut dengan formal region. Formal region didasarkan pada homogenitas atau kesamaan kondisi dengan kriteria tertentu antardaerah tetangganya, misalnya daerah iklim di Indonesia (Rustiadi, Saefulhakim, \& Panuju, 2009). Selain iklim matahari Indonesia berupa iklim tropis, iklim di Indonesia juga dibedakan lagi berdasarkan curah hujannya akibat pengaruh kondisi geografis yang berbeda. Indonesia di wilayah barat memiliki iklim hujan tropis dengan curah hujan yang tinggi, sedangkan iklim Indonesia tengah memiliki curah hujan dan kelembapan udara yang rendah. Adapun wilayah Indonesia bagian timur didominasi oleh hutan hujan tropis dan pegunungan dengan curah hujan lokal. Provinsi yang termasuk dalam Indonesia bagian barat misalnya Aceh, Sumatera Utara, Sumatera Selatan, Jawa Barat, Jawa Tengah, Jawa Timur, DKI Jakarta, dan sebagainya. Indonesia bagian tengah misalnya Bali, Sulawesi Selatan, Kalimantan Selatan, dan lainnya. Adapun provinsi yang termasuk Indonesia bagian timur misalnya Papua, Papua Barat, Maluku, dan Maluku Utara.

Berdasarkan kondisi iklim dan karakteristik wilayah yang ada tiap bagian di Indonesia, terdapat corak penyebaran COVID-19. Per 27 Juli 2020, peringkat pertama sampai kesepuluh provinsi dengan kasus COVID-19 terbanyak secara berurutan, yaitu Jawa Timur, DKI Jakarta, Sulawesi Selatan, Jawa Tengah, Jawa Barat, Kalimantan Selatan, Sumatera Utara, Sumatera Selatan, Bali, dan Papua (lihat Gambar 13.3). Data menurut Gugus Tugas Percepatan Penanganan COVID19 tersebut menunjukkan bahwa beberapa provinsi yang bertepatan pada Indonesia bagian barat menduduki peringkat tertinggi provinsi dengan infeksi virus COVID-19 terbanyak, disusul provinsi pada wilayah tengah, kemudian bagian timur. Beberapa provinsi bagian barat yang menduduki peringkat tertinggi tersebut yaitu Jawa Timur, DKI Jakarta, Jawa Tengah, Jawa Barat, Sumatera Utara, dan Sumatera Selatan. Provinsi pada wilayah bagian tengah yang menduduki peringkat tinggi, yaitu Sulawesi Selatan, Kalimantan Selatan, dan Bali. Adapun satu provinsi bagian timur, yaitu Papua, menempati peringkat kesepuluh. Tentunya penyebab tingginya kasus COVID-19 di kesepuluh provinsi tersebut memiliki banyak aspek kompleks yang dapat berbeda tiap wilayah selain dari faktor fisik (alam) yang ada, seperti tingginya penduduk yang menyebabkan tingginya mobilitas dan tingginya interaksi manusia. Perlu ditegaskan bahwa data yang ada bersifat dinamis. Seluruh wilayah di Indonesia tetap perlu meningkatkan kewaspadaan terhadap potensi penularan virus. 
Aplikasi Analisis Keruangan dalam Kebijakan Menghadapi Covid-19 di Indonesia

Kondisi iklim tropis serta temperatur dan kelembapan udara yang dimiliki Indonesia memang menunjukkan kondisi menguntungkan dengan tingkat kerentanan penyebaran COVID-19 yang relatif lebih kecil daripada wilayah dengan kondisi sebaliknya. Meskipun begitu, tidak semerta-merta masyarakat Indonesia hanya mengandalkan iklim dengan temperatur panas untuk mematikan virus. WHO menghimbau masyarakat untuk tidak menganggap virus mereda otomatis pada temperatur tinggi (panas). Hal ini berarti keuntungan iklim tropis Indonesia tidak boleh menyebabkan masyarakat menjadi lengah untuk memperhatikan protokol kesehatan beserta dengan upaya-upaya pencegahan yang dianjurkan pemerintah. Terbukti bahwa penyebab utama dari meledaknya penyebaran COVID-19 di Indonesia yang diketahui justru terjadi karena faktor lainnya, seperti mobilitas penduduk dan bentuk interaksi wilayah lainnya yang dilakukan (Sigler, et al., 2020).

Analisis keruangan dapat digunakan untuk melakukan prediksi penyebaran COVID-19. Penggunaan ruang serta perilaku manusia saat berinteraksi dalam suatu unit ruang tertentu dapat digunakan sebagai tolak ukur untuk mengetahui penyebaran COVID-19. Peningkatan jumlah kasus penyebaran COVID-19 salah satunya disebabkan oleh mobilitas yang tinggi. Tingginya mobilitas berbanding lurus dengan tingginya kerentanan penularan diakibatkan besarnya kemungkinan terjadinya kontak dengan kasus positif. Interaksi yang ada dapat diibaratkan dengan pemodelan difusi ekspansi dalam perspektif keruangan geografi. Virus COVID-19 berawal dari Wuhan, China, yang kemudian mengalami ekspansi ke berbagai penjuru negara dunia dengan penyebaran penyakit bersamaan dengan interaksi dan mobilitas penduduk dari satu daerah ke daerah lain sehingga memungkinkan penambahan kasus baru yang kian meningkat (Sigler, et al., 2020). Pada prosesnya, wabah yang berdifusi tetap ada dan kadang lebih intensif di tempat asalnya. Artinya, ada proses penambahan jumlah baru pada populasi antara dua waktu serta daerah asal terjangkit mengalami perluasan.

Mobilitas penduduk merupakan perpindahan penduduk dari suatu unit geografis (wilayah) satu ke unit geografis lainnya dengan alasan tertentu, seperti alasan sosial, ekonomi, pendidikan, dan lainnya (Mantra \& Pitoyo, 1998; Sadali \& Rijanta, 2014). Mobilitas penduduk dapat dibedakan menjadi 2 (dua), yaitu mobilitas vertikal dan horizontal. Mobilitas vertikal sering disebut sebagai perubahan status yang melekat pada suatu individu, misalnya perubahan status pekerjaan. Mobilitas horizontal sering disebut sebagai perpindahan penduduk secara geografis, yaitu gerak yang melintasi region (wilayah) satu ke wilayah lainnya dalam periode waktu tertentu dengan alasan yang beragam, seperti alasan 
untuk menuju ke wilayah yang lebih berpotensi. Hal ini didasarkan atas konsep geografi, yaitu konsep ruang dan waktu.

Pada dasarnya, mobilitas penduduk tidak terhindarkan mengingat banyaknya kebutuhan manusia yang perlu dipenuhi dan membutuhkan pergerakan sebagai syarat pemenuhan kebutuhan tersebut. Pemenuhan kebutuhan dapat dikaitkan dengan teori lokasi dalam analisis keruangan, yaitu adanya sumber potensial pada suatu ruang wilayah dengan aktivitasnya serta memiliki pengaruh dan hubungan (ikatan) antarruang yang didasari alasan tertentu (ekonomi, sosial, lingkungan, dan lainnya). Di dalam analisis keruangan, mobilitas penduduk merupakan bentuk dari proses difusi keruangan dan interaksi keruangan, karena terjadi perpindahan manusia maupun material dan pemenuhan kebutuhan melalui demand-supply wilayah. COVID-19 Hubungan antarruang tersebut menyebabkan terjadinya interaksi yang dapat meningkatkan potensi penyebaran COVID-19.

Distribusi penyebaran COVID-19 dapat terjadi dalam skala satuan luas wilayah kecil dan besar. Keterkaitan wilayah dalam lingkup yang besar, seperti distribusi kebutuhan antarwilayah, berpotensi terjadinya penyebaran COVID-19 dalam prosesnya. Proses pemenuhan kebutuhan, terdapat suatu wilayah yang memegang peranan krusial untuk memenuhi atau melayani kebutuhan wilayah lainnya karena komoditas dan karakteristik unik tertentu. Hal ini sejalan dengan Central Place Theory yang dikemukakan oleh (Christaller, 1933) dengan wilayah yang memegang peranan krusial tersebut dinamakan sebagai tempat pusat. Tempat pusat memiliki tingkat aktivitas yang tinggi dengan menandakan adanya suatu pusat kota yang menyebabkan banyaknya mobilitas karena merupakan daerah pusat, misalnya Jakarta. Jakarta merupakan kota pusat pertumbuhan Indonesia dan berkedudukan sebagai pusat kegiatan nasional, seperti pusat pelayanan pasar optimum, pusat lalu lintas dan transportasi, pusat ekonomi, dan pusat pemerintahan. Kasus COVID-19 pertama di Indonesia pun berawal di Jakarta yang setelah ditelusuri diketahui Kasus 01 (pertama) melakukan kontak dengan warga negara Jepang di acara dansa Klub Amigos Jakarta Selatan pada pertengahan Februari 2020 lalu. Hingga saa ini, jumlah kasus di tempat pusat pelayanan masih dominan (tinggi). Gambar 13.3 menunjukkan DKI Jakarta dan Surabaya (Provinsi Jawa Timur) sebagai tempat pusat pelayanan di Indonesia menjadi episentrum kasus COVID-19 dengan kasus paling banyak.

Analisis keruangan sangat bermanfaat dalam mengidentifikasi dan memahami penyebaran infeksi dari sebuah penyakit, asosiasi keruangan (spatial association) menjadi kunci dari tahap awal penyebaran pandemi COVID-19 di dataran China (Kanga, Choi, Kim, \& Choi, 2020). Aplikasi analisis keruangan 
Aplikasi Analisis Keruangan dalam Kebijakan Menghadapi Covid-19 di Indonesia

dengan menggunakan metode sebaran lokasi (poin pattern)/node dapat memberikan gambaran sebaran lokasi (wilayah) yang terpapar COVID-19. Deteksi awal lokasi/wilayah yang terinfeksi atau terdapat kasus COVID-19 dapat mengantisipasi dan mencegah penyebaran yang lebih luas. Kasus COVID-19 yang muncul pada beberapa daerah di Indonesia secara umum berawal dari wilayah perkotaan dan kemudian menyebar ke daerah-daerah sekitarnya. Pada Gambar 13.3, jumlah kasus ditunjukkan oleh node (titik) merah dengan ukuran berbeda-beda, yang berarti semakin besar titik merah maka semakin banyak kasus COVID-19 yang terdapat di provinsi tersebut. Data dari Satuan Tugas Penanganan COVID-19 Indonesia, wilayah di Indonesia yang berstatus kota (97 kota) sebagian besar juga berada dalam zona resiko tinggi (15 kota) dan zona resiko sedang (56 kota). Kota-kota di Indonesia yang termasuk ke dalam zona kuning/resiko rendah sebanyak 25 kota, sedangkan kota yang tidak ada kasus COVID-19 di Indonesia hanya 1, yaitu Kota Singkawang di Provinsi Kalimantan Barat. Hasil analisis pewilayahan ini menjadi salah satu pertimbangan bagi pemerintah daerah untuk mengambil kebijakan dalam menanggulangi maupun mencegah meningkatnya kasus COVID-19 di daerahnya masing-masing.

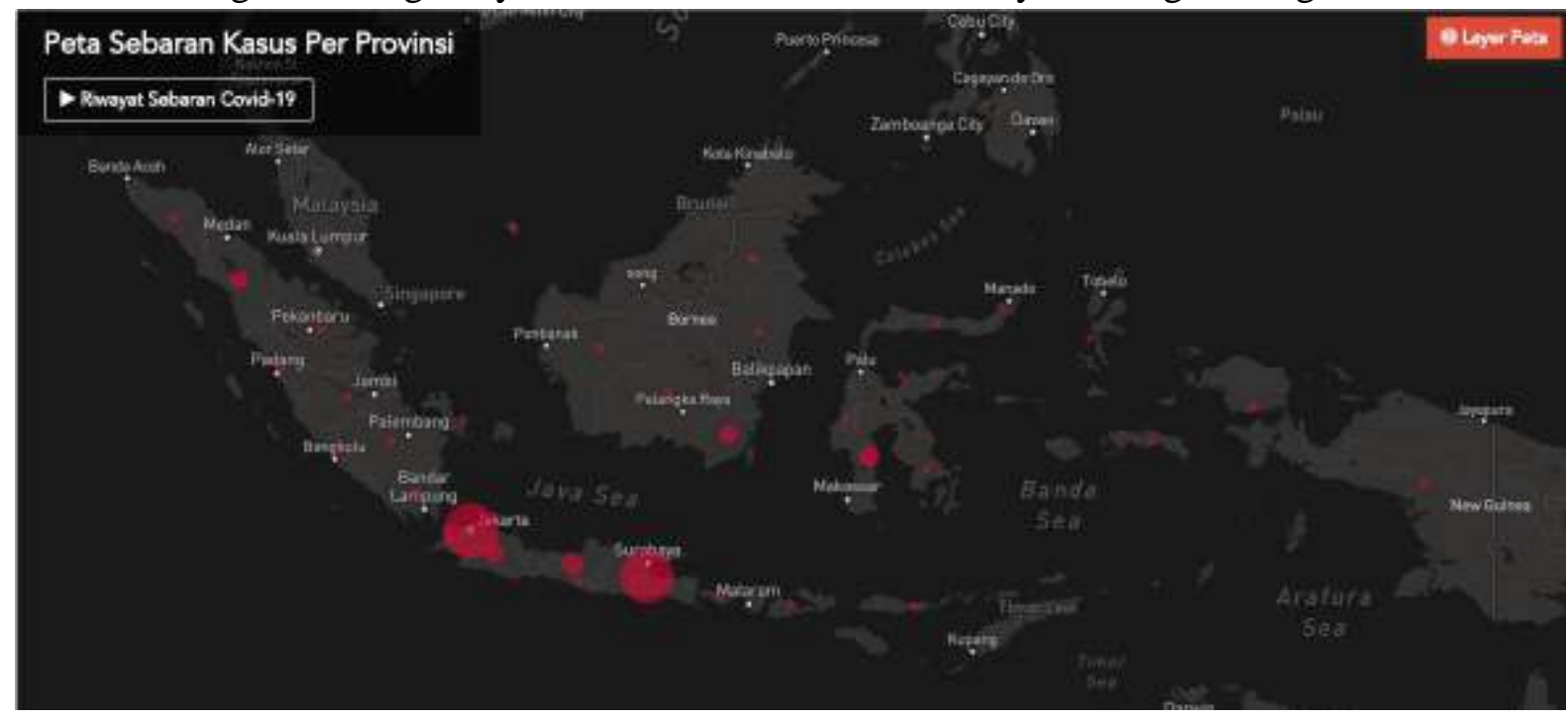

Gambar 13.3 Peta Lokasi Sebaran Kasus COVID-19 Menurut Provinsi di Indonesia, Agustus 2020

Sumber: https://covid19.go.id/peta-sebaran

Tempat pusat merupakan tempat yang rawan terjadi penyebaran COVID19 dikarenakan tingginya mobilitas tersebut dan interaksi antarorang. Adanya pusat tersebut menyebabkan banyak orang melakukan mobilitas "dari" dan "ke" daerah pusat untuk memenuhi berbagai kebutuhan. Mobilitas yang terjadi lokal 
dalam negera maupun internasional berpotensi menciptakan interaksi antarorang. Kondisi kontak dengan warga negara lain, terutama yang memiliki riwayat berpergian dari luar negeri, sangat rentan untuk terjadi penularan epidemi dan pendemi virus seperti COVID-19 (Merler \& Ajelli, 2012). Penyebaran COVID19 sangat rentan di penerbangan, terlebih penerbangan internasional, dikarenakan adanya interaksi yang intens antarmanusia yang mungkin di antaranya terdapat kasus positif. Waktu bersama dengan kasus positif pun tergolong panjang mengingat penerbangan terjadi pada ruang yang terbatas dan dalam waktu tertentu tergantung pada jauhnya jarak yang dituju. Terlebih mobilitas yang terjadi pada ruang sempit dalam pesawat, misalnya dengan pergi ke toilet, menyebabkan interaksi intens antarmanusia. Upaya untuk menangani kondisi tersebut yaitu dengan melakukan pemeriksaan di bandara, seperti mengukur suhu, memberi cairan pembunuh kuman, dan mengisi data kesehatan. Pemerintah Indonesia dapat menggunakan data tersebut sebagai pelengkap data acuan sehingga dapat dilakukan penanganan dini untuk memutus rantai penyebaran COVID-19 pada mobilitas penduduk dari Sabang sampai Merauke mengingat luasnya wilayah Indonesia.

Wilayah perkotaan rentan dalam menghadapi krisis global ini. Tingginya kerentanan dikarenakan perkotaan memiliki konektivitas baik dalam skala regional maupun skala global. Kota memiliki daya tarik penduduk akan kehidupan yang lebih baik, terutama dalam bidang perekonomian. Selain itu, perkotaan juga menyediakan fasilitas pelayanan publik yang lengkap. Kondisi ini meningkatkan minat untuk tinggal di perkotaan yang menyebabkan kepadatan kota semakin meningkat dan menyebabkan kenaikan permintaan lahan perumahan. Sayangnya, peningkatan jumlah lahan tersebut tidak sebanding dengan ketesediaan lahan yang ada sehingga membuat harga lahan (land cost) meningkat. Penduduk yang tidak mampu akan cenderung memilih bertempat tinggal pada permukiman yang kurang layak (Ritohardoyo \& Sadali, 2017). Tak heran, banyak permukiman kumuh dan padat di perkotaan. Kondisi permukiman kumuh dan padat ini menjadi sasaran ideal bagi penyebaran COVID-19. Perkotaan juga banyak menyediakan perumahan vertikal akibat rendahnya ketersediaan lahan. Perumahan vertikal, seperti rusun (rumah susun) dan apartemen, memungkinkan penyebaran COVID-19 yang lebih tinggi. Alasannya yaitu penghuninya diharuskan untuk berbagi fasilitas dengan penghuni lain, misalnya berbagi lift, koridor, tangga, dan fasilitas lainnya. Selain itu, banyaknya penghuni dalam satu bangunan menyebabkan ruang gerak yang tersedia lebih sempit. 
Aplikasi Analisis Keruangan dalam Kebijakan Menghadapi Covid-19 di Indonesia

Wilayah padat penduduk memiliki jumlah kasus COVID-19 yang tinggi (Sigler, et al., 2020). Padat penduduk akan menaikan potensi untuk berpapasan dengan orang banyak. Akan tetapi, padat penduduk bukan satu-satunya penyebab tingginya angka penularan COVID-19. Terdapat kasus yang membuktikannya, yaitu ada di Kelurahan Pegadungan, Kalideres, Jakarta Barat. Lokasi tersebut sempat menjadi lokasi dengan jumlah kasus positif COVID-19 tertinggi di Jakarta. Kepadatan penduduk di lokasi tersebut tidak terlalu tinggi. Patokan duga terjadinya kondisi tersebut adalah dekatnya lokasi yang ada dengan Bandara Soekarno-Hatta. Asumsi tersebut tumbuh mengingat bandara merupakan gerbang pertama pintu masuknya virus COVID-19 dari dalam maupun luar negeri. Dekat dengan kawasan perkotaan, kawasan sub urban memiliki tingkat kemungkinan transmisi yang lebih rendah dari kawasan urban (perkotaan). Kawasan sub urban sendiri dapat terjadi karena tingginya laju urbanisasi yang tidak terkontrol sehingga memungkinkan terjadinya ekspansi wilayah. Kemungkinan lebih rendahnya transmisi di sub urban dikarenakan kegiatan atau aktivitas penduduk lebih berada di kawasan urban. Selain itu, kepadatan penduduk yang lebih rendah juga akan lebih menghalangi transmisi virus.

Tantangan yang dihadapi penduduk sub urban, yaitu fasilitas kesehatan yang kurang memadai dan jauhnya akses menuju ke fasilitas kesehatan. Penyebaran COVID-19 tadinya baru gencar pada daerah perkotaan. Akan tetapi tak lama setelahnya, penyebaran juga terjadi di desa. Total desa di Indonesia berjumlah lebih dari 83 ribu desa yang sampai Juli 2020 ini belum terpapar semua. Sebelum dilakukannya intervensi nonmedis dengan pembatasan mobilitas yang gencar terjadi di perkotaan, banyak perantau yang berbondong-bondong pulang kampung karena berbagai alasan pribadi. Desa menjadi titik pulang untuk pemudik yang berpotensi picu penyebaran COVID-19 lebih luas lagi. Hal ini dikarenakan banyak penduduk yang sebelumnya tinggal di zona merah (red zone) seperti Jakarta, Medan, Palembang, Karo, Buton, Jayapura, dan lainnya yang kemungkinan terpapar positif COVID-19 namun tidak menunjukkan gejala (asimtomatik) melakukan mudik ke daerah asalnya. Proses saat melakukan mudik tersebut tentunya akan membuat banyak kontak dengan penduduk lain yang dapat memperpanjang rantai penularan.

Desa dapat menjadi garda terdepan dalam penularan COVID-19. Walaupun penyebaran masih lebih banyak di area perkotaan, penyebaran di desa akan lebih beresiko. Banyak faktor yang menyebabkan desa lebih rentan pada penularan COVID-19. Faktor-faktor yang ada sejalan dengan karakteristik masyarakat desa, misalnya masih tingginya interaksi antarmasyarakat desa dikarenakan hubungan kekerabatan (sosial) yang masih kental di desa. 
Rendahnya literasi masyarakat desa juga menjadi faktor rentan penularan COVID-19 pada masyarakat desa. Terlebih cara pandang masyarakat desa yang kebanyakan masih tertutup dan tak sedikit yang masih berpegang teguh pada kepercayaan tertentu yang berlaku di desa. Pemahaman masyarakat desa tersebut sebenarnya tidak untuk memberikan diskriminasi sosial, melainkan sebagai nilai positif yang perlu dijaga kelestariannya, selama hal tersebut tidak bertentangan dengan protokol kesehatan nasional mengenai penanganan COVID-19.

Rendahnya tingkat teknologi masyarakat desa juga dapat menjadi faktor penghambat untuk terus memperbaharui informasi terkait COVID-19, mengingat perkembangan yang masih sangat dinamis karena virus ini merupakan virus jenis baru sehingga masih banyak studi yang perlu dilakukan untuk terus mengkaji lebih dalam guna mengentaskan pandemi secepat mungkin. Faktor lainnya yaitu usia penduduk di desa kebanyakan ada di kalangan lanjut usia (lansia) karena masyarakat usia remaja dan produktif cenderung melakukan perantauan ke wilayah perkotaan dengan motif ekonomi. WHO menyebutkan bahwa penduduk lansia, yaitu penduduk dengan usia 60 tahun ke atas, memiliki tingkat kerentanan terpapar virus COVID-19 lebih tinggi. Resiko terserang penyakit serius atau kronis juga tergolongkan pada kelompok lansia karena penurunan kemampuan fisik seiring bertambahnya usia.

Tingginya kasus COVID-19 yang menyebabkan meningkatnya korban jiwa penduduk Indonesia menimbulkan urgensi penanganan pandemi. Partisipasi publik dalam pencegahan dan penanganan COVID-19 sangat diperlukan untuk mengendalikan kasus. Pemantauan kasus COVID-19 perlu dilakukan dengan baik, tak terkecuali kemungkinan ditemukannya kasus di desa. Partisipasi masyarakat desa harus disertakan untuk menghindari kemungkinan terburuk bagi desa. Edukasi kepada masyarakat desa perlu digalakkan untuk menyebarluaskan informasi yang benar melalui penyampaian yang jelas dan sederhana sehingga diketahui upaya pencegahan serta penanganan yang sesuai. Jalan yang ditempuh Kemenkes yaitu dengan menyediakan informasi praktis dengan penjelasan sederhana mulai dari informasi dasar pengertian COVID-19, upaya pencegahan, upaya penanganan, cara untuk membuat disinfektan berbahan baku lokal yang mudah ditemukan di desa, dan sebagainya. Adapun upaya pendukung yang dilakukan Kemendagri dengan menugaskan pembentukan suatu tim kedaruratan kesehatan masyarakat desa guna meningkatkan kesiapsiagaan desa dalam menghadapi COVID-19.

Ketaatan masyarakat desa dalam menyikapi peraturan dan kebijakan yang dibuat pemerintah akan sangat membantu. Menurut Kemendes (Wibowo, 2020), $53 \%$ desa di Indonesia telah membentuk relawan desa lawan COVID-19. Hal 
yang dapat dan telah dilakukan banyak desa, yaitu dengan membentuk pos jaga pada jalan-jalan tertentu di desa. Pos jaga yang ada akan memantau mobilitas warga yang keluar masuk desa dengan warga yang masuk ke desa akan disediakan cairan disinfektan. Pemantauan juga dilakukan pada pemudik yang tiba di desa, mengingat tingkat kerentanan penyebaran COVID-19 akibat pemudik tersebut. Menyikapi hal tersebut, desa-desa berupaya menyediakan fasilitas isolasi atau karantina selama 14 hari pada penduduk yang baru tiba dari luar kota. Penyediaan posko dan ruang isolasi telah diterapkan di sejumlah desa di Palembang, Sumatera Selatan. Posko isolasi yang ada dibentuk di berbagai tempat, seperti sekolah, balai desa, atau rumah warga yang dipinjamkan. Isolasi tersebut dilaksanakan dengan pengawasan ketat di bawah pengawasan polisi, TNI, dan Dinas Kesehatan setempat. Beberapa desa di Gresik, Jawa Timur, juga bertindak cepat dalam penanganan pandemi COVID-19 dengan menyediakan ruang isolasi bagi pendatang luar kota. Desa melalui himbauan pemerintah juga melaksanakan penyemprotan disinfektan hingga ke rumah warga. Giat penyemprotan disinfektan contohnya dilakukan oleh BPBD Kebumen, Jawa Tengah, pada fasilitas pendidikan, fasilitas kesehatan, serta rumah warga dengan penyemprotan rumah lebih difokuskan ke rumah warga yang memiliki hasil swap positif. Sejatinya desa-desa yang tersebar di Indonesia telah melakukan upaya pencegahan penularan COVID-19. Tindakan yang cerdas oleh masyarakat dari unit terkecil sangat dibutuhkan untuk menumpas pandemi COVID-19. Semakin gencar informasi mengenai COVID-19 dilakukan di berbagai pelosok negeri diharapkan dapat meningkatkan tingkat partisipasi penduduk dalam langkah pencegahan dan penanganan COVID-19.

Analisis keruangan bersama sistem informasi geografis dapat digunakan untuk melakukan prediksi lamanya waktu COVID-19 dengan melakukan pemetaan terkait mobilisasi yang ada. Mobilisasi tersebut berhubungan pula dengan interaksi manusia dengan keruangannya. Penyebaran COVID-19 dapat terjadi karena interaksi dengan penduduk positif COVID-19. Semakin banyak mobilisasi maka perkiraan waktu berakhirnya pandemi akan semakin lama. Melalui pemetaan dapat diketahui record atau track kemungkinan penyebaran COVID-19. Metode pengumpulan data terbaru perlu diterapkan untuk memperbaharui data dinamis. Peran Big Data sangat berpengaruh dalam mendukung keterpaduan data. Keterbatasan mobilitas yang terjadi di tengah pandemi memberikan pekerjaan baru untuk lebih fokus ke riset data digital sehingga diperlukan penguasaan metode digital demi memaksimalan data digital. Hasil dari pengolahan data digital tersebut dapat dipublikasikan pada laman valid untuk akses umum. Hal ini dikarenakan masyarakat juga membutuhkan informasi 
terbaru tiap harinya pada sumber terpercaya terkait perkembangan COVID-19. Sumber terpercaya saat ini sangat dibutuhkan untuk menapis berita salah (hoax atau fake news) yang kian beredar di media sosial. Beredarnya informasi terpercaya dapat menyumbang pengetahuan akan pemutusan rantai penyebaran COVID-19.

Aplikasi analisis keruangan yang digunakan pemerintah dalam menentukan wilayah beresiko mengalami kenaikan kasus COVID-19 dilakukan dengan menggunakan pewilayahan atau regionalisasi. Hasil pewilayahan membentuk zona-zona yang dituangkan dalam bentuk peta zonasi yang membagi wilayah-wilayah beresiko ke dalam 5 kelas, dengan simbol sebagai berikut: zona merah (resiko tinggi), zona oranye (resiko sedang), zona kuning (resiko rendah), zona hijau (tidak ada kasus dan tidak terdampak). Proses analisis keruangan (regionalisasi) yang dilakukan pemerintah untuk menentukan wilayah dengan zona resiko tertentu menggunakan skor dan bobot pada indikator terpilih. Penentuan zona resiko pada daerah-daerah di Indonesia berdasarkan pada data valid dan kajian yang dianalisis tim pakar Gugus Tugas Nasional. Terdapat 15 indikator utama, yang terdiri dari indikator kesehatan masyarakat, yang terbagi menjadi 11 indikator epidemiologi, dua indikator surveilans kesehatan masyarakat dan dua indikator pelayanan kesehatan (Arifin, 2020).

Peta zonasi resiko yang dipublikasikan oleh Satuan Tugas Penanganan COVID-19 Indonesia menunjukkan status resiko kenaikan kasus COVID-19 menurut kabupaten/kota di Indonesia (lihat Gambar 13.4). Berdasarkan hasil pewilayahan resiko COVID-19 yang dilakukan pemerintah pada bulan Agustus 2020, sebagaian besar wilayah Indonesia masuk dalam zona resiko sedang $(43,19 \%)$ dan zona resiko rendah $(34,44 \%)$. Pada level ketiga (zona oranye atau risiko sedang) risiko penyebaran COVID-19 pada level ini tinggi dan potensi virus tidak terkendali. Pada level ini, transmisi lokal hingga imported case kemungkinan dapat terjadi dengan cepat. Pemerintah di daerah harus memantau kluster-kluster baru dan mengontrol pergerakan melalui testing dan tracking yang agresif. Oleh karena itu, seluruh masyarakat terutama kelompok rentan yang berada di daerah dengan status zona oranye disarankan untuk tetap berada di rumah, bekerja dari rumah kecuali untuk fungsi-fungsi tertentu. Apabila harus keluar rumah diwajibkan untuk selalu menjaga jarak di semua aspek. Penumpang transportasi umum dibatasi dan wajib menerapkan protokol kesehatan. Tempattempat dan fasilitas umum termasuk sekolah ditutup. Kegiatan bisnis hanya dibuka secara terbatas selain keperluan esensial seperti farmasi, supermarket bahan pokok, klinik kesehatan, stasiun bahan bakar dengan tetap menerapkan physical distancing (Arifin, 2020). 


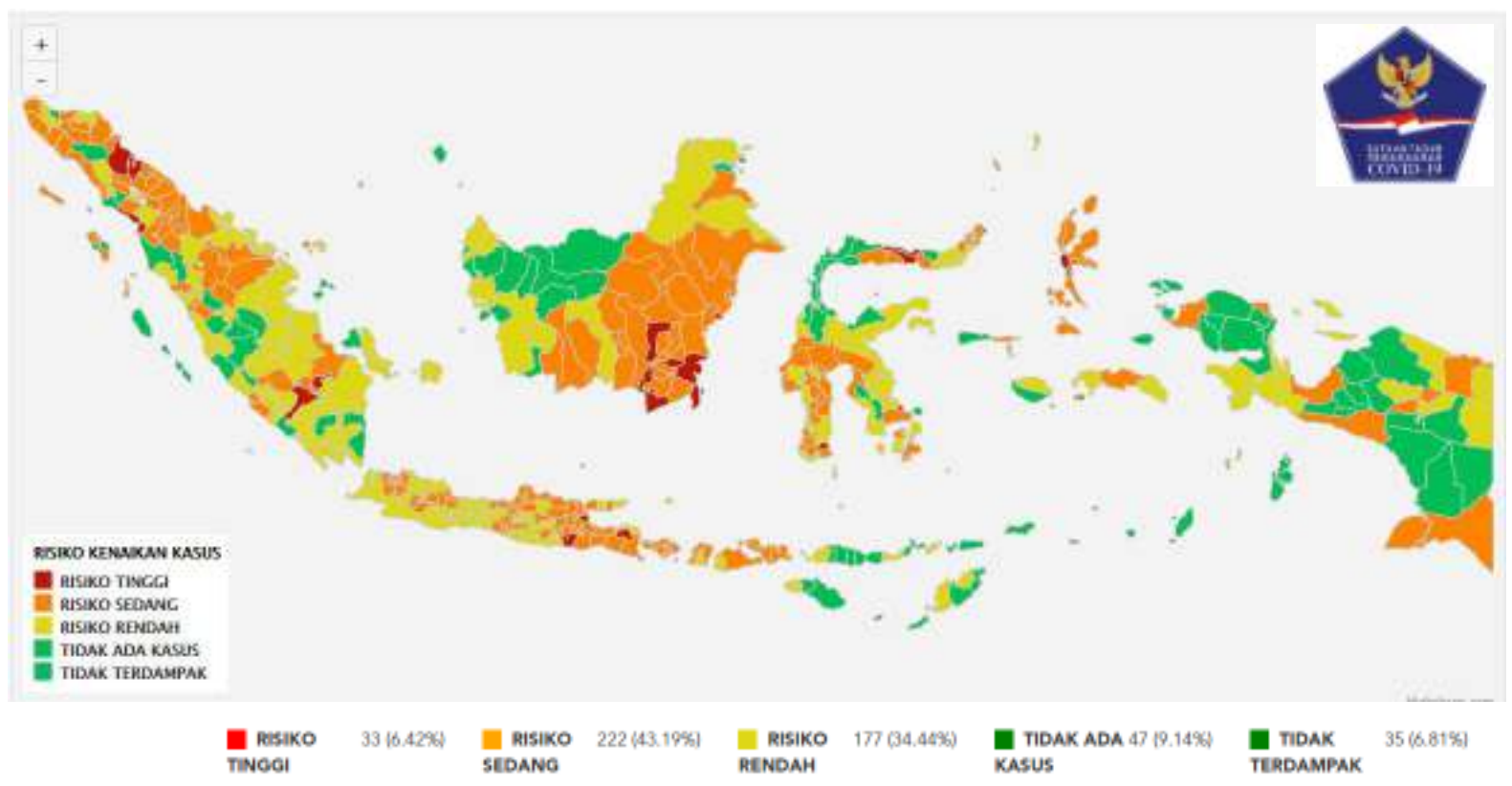

Gambar 13.4 Peta Zonasi Resiko Terdampak COVID-19 Menurut Kabupaten/Kota di Indonesia, Agustus 2020

Sumber: https://covid19.go.id/peta-risiko

Kabupaten/kota di Indonesia yang termasuk dalam zona merah atau zona resiko tinggi berjumlah 33 kabupaten/kota $(6,42 \%)$, sedangkan yang berstatus tidak ada kasus dan tidak terdampak masing-masing berjumlah 47 kabupaten/kota $(9,14 \%)$ dan 35 kabupaten $(6,81 \%)$. Menurut BNPB, pada level ini, penyebaran virus SARS-CoV-2 atau korona jenis baru penyebab COVID-19 tidak terkendali. Transmisi lokal sudah terjadi dengan cepat, wabah menyebar secara luas dan banyak kluster-kluster baru. Pada kondisi ini, pemerintah di daerah wajib melakukan testing yang intensif dan penelusuran kontak secara agresif pada kasus ODP dan PDP. Masyarakat harus berada di rumah, aktivitas seperti perjalanan, pertemuan publik, belajar mengajar dan kegiatan keagamaan tidak diperbolehkan. Kegiatan bisnis ditutup kecuali untuk keperluan yang bersifat esensial seperti farmasi, supermarket bahan pokok, klinik kesehatan, dan stasiun bahan bakar. Selain itu, tempat-tempat umum, area publik/keramaian, fasilitas sekolah juga ditutup untuk mencegah dan menghentikan laju penyebaran virus.

Salah satu contoh kebijakan pemerintah daerah yang merupakan respon dari hasil pewilayahan resiko kenaikan kasus COVID-19 di daerah adalah Pembatasan Sosial Berskala Besar (PSBB). Upaya pemerintah dalam memutus mata rantai penyebaran COVID-19 melalui PSBB faktanya dapat menekan laju penularan COVID-19. Meskipun demikian, tidak semua daerah siap mengambil kebijakan PSBB karena dampak terhadap aspek ekonomi maupun sosial cukup 
besar. Perlu kesiapan dan dukungan seluruh pihak agar pemberlakuan PSBB juga dapat efektif dan efisien. Kebijakan lain yang diberlakukan untuk memutus rantai penyebaran COVID-19 dilakukan dengan pembatasan interaksi langsung, sehingga pemerintah menghimbau untuk melakukan social distancing/physical distancing untuk flatten the curve. Physical distancing dilakukan untuk mengurangi resiko transmisi COVID-19 dengan menjaga jarak aman minimal 1 meter antarorang atau per jarak personalnya. Membangun tatanan baru (new normal) menjadi penting bersamaan dengan situasi pandemi ini. Semua hal yang berkaitan dengan new normal membutuhkan perencanaan matang beserta kebijakan yang menyertainya. Diharapkan praktek dari perencanaan tersebut dapat mengantisipasi pandemi sedini mungkin. Kondisi sekarang mengharuskan untuk melakukan physical distancing, terlebih di ruang publik.

\section{Kesimpulan}

Berdasarkan hasil kajian yang telah dilakukan, dapat diketahui bahwa analisis keruangan dapat dijadikan sebagai bahan maupun bagian dari kebijakan menghadapi COVID-19 di Indonesia. Analisis keruangan berupa titik (point) diaplikasikan untuk melihat jumlah kasus dan sebarannya di satuan wilayah tertentu secara administrasi, sedangkan analisis keruangan berupa area dimanfaatkan untuk melakukan regionalisasi atau menentukan wilayah menurut zona resiko terdampak COVID-19. Di masa COVID-19 ini, analisis keruangan juga dapat menjadi alat yang penting dalam pengambilan keputusan atau kebijakan, terlebih untuk menganalisis pergerakan manusia yang merupakan obyek terdampak dan bagian dari subyek pembawa virus. Antisipasi pencegahan dan penyebaran kasus COVID-19 di Indonesia dapat ditekan dan terus diminimalisir lebih awal dengan analisis keruangan yang lebih komprehensif serta konsisten dengan kebijakan yang diambil (ditegakkan).

\section{E. Ucapan terima kasih}

Penulis menyampaikan banyak terima kasih kepada Departemen Geografi Pembangunan dan Fakultas Geografi UGM yang memberikan kesempatan kepada penulis untuk berkarya melalui tulisan di buku ini.

\section{F. Daftar Pustaka}

Aksa, F. I., Utaya, S., \& Bachri, S. (2019, Maret). Geograi dalam Perspektif Filsafat Ilmu. Majalah Geograi Indonesia, 33(1), 43-47. doi:10.22146/mgi.35682 
Aplikasi Analisis Keruangan dalam Kebijakan Menghadapi Covid-19 di Indonesia

Araujo, M. B., \& Naimi, B. (2020, April 7). Spread of SARS-CoV-2 Coronavirus Likely to be Constrained by Climate. 1-26. doi:https://doi.org/10.1101/2020.03.12.20034728

Arifin, D. (2020, Juni 10). Pengelompokan Kriteria Risiko COVID-19 di Daerah Berdasarkan Zonasi Warna. (BNPB) Diambil kembali dari Berita: Pengelompokan Kriteria Risiko COVID-19 di Daerah Berdasarkan Zonasi Warna: https://bnpb.go.id/

Bintarto, R., \& Hadisumarno, S. (1979). Metode Analisa Geografi. Jakarta: Lembaga Penelitian Pendidikan dan Penerangan Ekonomi dan Sosial.

Chen, N., Zhou, M., Dong, X., Qu, J., Gong, F., Han, Y., . . Zhang, L. (2020, February 15). Epidemiological and clinical characteristics of 99 cases of 2019 novel coronavirus pneumonia in Wuhan, China: a descriptive study. Lancet, 395, 507-513. doi:https://doi.org/10.1016/S0140-6736(20)302117

Christaller, W. (1933). Central Place in Southern Germany. (C. W. Baskin, Penerj.) New Jersey: Prentice-Hall.

Haggett. (1983). Geography: A Modern Synthesis. New York: Harper \& Row.

Islam, N., Shabnam, S., \& Erzurumluoglu, A. M. (2020, March 31). Temperature, Humidity, Wind Speed are Associated with Lower COVID-19 Incidence. 1-4. doi:https://doi.org/10.1101/2020.03.27.20045658

Kanga, D., Choi, H., Kim, J.-H., \& Choi, J. (2020). Spatial Epidemic Dynamics of the COVID-19 Outbreak in China. International Journal of Infectious Diseases, 94, 96-102. doi:https://doi.org/10.1016/j.ijid.2020.03.076

Kementerian Kesehatan. (2020, Maret 16). Dashboard Data Kasus Covid-19 di Indonesia. Diambil kembali dari Kementerian Kesehatan Republik Indonesia: htpps://www.kemenkes.go.id/

Kementerian Kesehatan. (2020). Keputusan Menteri Kesehatan No. HK.01.07/MENKES/413/2020 tentang Pedoman Pencegahan dan Pengendalian Corona Virus Desease 2019 (Covid-19). Jakarta:

Sekertariat Jenderal Kementerian Kesehatan. 
Aplikasi Analisis Keruangan dalam Kebijakan Menghadapi Covid-19 di Indonesia

Luiseto, M., Rafa, A. Y., Edbey, K., Mashori, G. R., Ahmad, F., \& Latyshev, O. Y. (2020, April 7). Epidemiology and Difusion of Some Relevant Virus: Laitude, Air Pollutants and Humidity Role, Hypothesis of Work: Covid19 Efect on the Air Polluion in Some World Region: What Implicaions? Journal of Toxicology and Risk Assessment, 6(1), 1-12. doi:10.23937/2572-4061.1510031

Mantra, I. B., \& Pitoyo, A. J. (1998). Kumpulan Beberapa Teori Mobilitas Penduduk (Vol. Buku I \& II). Yogyakarta: Universitas Gadjah Mada.

Merler, S., \& Ajelli, M. (2012). Hman Mobility and Population Heterogeneity in The Spreat of An Epidemic. Procedia Computer Science 1 (hal. 22372244). Italy: Elsevier Ltd. doi:10.1016/j.procs.2010.04.250

Mona, N. (2020). Konsep Isolasi dalam Jaringan Sosial Untuk Meminimalisasi Efek Contagious (Kasus Penyebaran Virus Corona di Indonesia). Jurnal Sosial Humaniora Terapan, 2(2), 117-125.

Ritohardoyo, S., \& Sadali, M. I. (2017, November ). Kesesuaian Keberadaan Rumah Tidak Layah Huni (RTLH) terhadap Tata Ruang Wilayah di Kota Yogyakarta. Tata Loka, 19(4), 291-305. doi:https://doi.org/10.14710/tataloka.19.4.291-305

Rustiadi, E., Saefulhakim, S., \& Panuju, D. R. (2009). Perencanaan dan Pengembangan Wilayah (2 ed.). Jakarta: Yayasan Pustaka Obor Indonesia.

Sadali, M. I., \& Rijanta, R. (2014). Mobilitas Pekerja Pada Kawasan Industri Piyungan di Kabupaten Bantul, Daerah Istimewa Yogyakarta. Yogykakarta: Universitas Gadjah Mada.

Sigler, T., Mahmuda, S., Kimpton, A., Loginova, J., Wohland-Jakhar, P., Charles-Edwards, E., \& Corcoran , J. (2020). The Socio-Spatial Determinants of COVID-19 Diffusion: The Impact of Globalisation, Settlement Characteristics and Population. 1-26. doi:https://doi.org/10.21203/rs.3.rs-33615/v1

Suharyono, \& Amien, M. (1994). Pengantar Filsafat Geografi. Jakarta: Dirjen DIKTI-DEPDIKBUD. 
Aplikasi Analisis Keruangan dalam Kebijakan Menghadapi Covid-19 di Indonesia

Sumaatmadja, N. (1988). Studi Geografi Pendekatan dan Analisa Keruangan. Bandung: Alumni.

Wibowo, A. (2020, April 19). Lebih dari 40 Ribu Desa Bentuk Relawan Desa Lawan COVID-19. (D. Arifin, Editor, \& D. Arifin, Produser) Diambil kembali dari Berita: htpps://bnpb.go.id 


\section{Mohammad Isnaini Sadali}

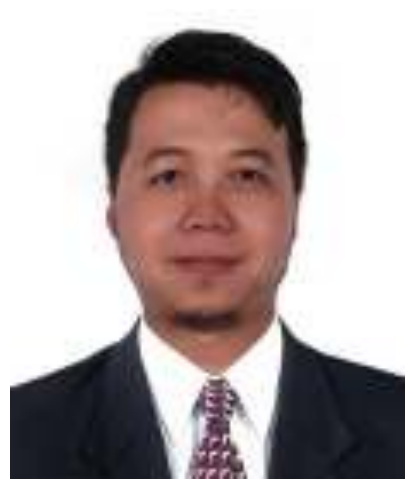

Mohammad Isnaini Sadali, S.Si., M.Sc. lahir di Yogyakarta 35 tahun yang lalu atau lebih tepatnya pada tanggal 24 April 1984. Penulis mengenyam pendidikan dari sekolah dasar hingga sekolah menengah atas di Yogyakarta kemudian melanjutkan kuliah Sarjana (S1) di Prodi Pembangunan Wilayah, Fakultas Geografi UGM dan Master (S2) Pasca Sarjana UGM. Saat ini penulis sedang menempuh pendidikan Doktor (S3) di Fakultas Geografi UGM. Penulis memiliki seorang istri yang bekerja sebagai dokter, menjadikan penulis tergerak menulis mengenai COVID-19. Selama 8 tahun hingga sekarang penulis mengabdi sebagai pengajar di Program Studi Pembangunan Wilayah Fakultas Geografi UGM. Penulis aktif dalam menulis buku, beberapa hasil karya (berupa buku) yang telah dihasilkan oleh penulis adalah Keistimewaan Lingkungan Daerah Istimewa Yogyakarta, Aplikasi Decision Support System (DSS) dalam Pembangunan Wilayah, Revitalisasi "Eko"nomics dan "Eko"logy Menuju Transmigrasi 4.0, dan Permukiman Kumuh di Pinggiran Kota (Kasus di Pinggiran Kota Yogyakarta). Penulis juga mempublikasikan beberapa tulisannya bersama penulis lain dalam bentuk jurnal maupun prosiding internasional dan nasional yang bisa ditemukan di: Geografia-Malaysian Journal of Society and Space (jurnal), IOP Conference Series: Earth and Environmental Science (prosiding), E3S Conferences (prosiding), Sixth Geoinformation Science Symposium (prosiding), Tata Loka (jurnal), Jurnal Pendidikan Geografi , Jurnal Geografi, dan Media Komunikasi Geografi (jurnal). Sebagai bentuk pengabdian, penulis juga pernah terlibat aktif dalam penyusunan dokumen perencanaan pembangunan (RPJPD, RPJMD, Rencana Induk), perencanaan tata ruang (RTRW, RDTR, RTBL), dan dokumen perencanaan wilayah lainnya di beberapa daerah Indonesia. 


\section{Penerbit:}

Badan Penerbit Fakultas Geografi (BPFG) Universitas Gadjah Mada

Perpustakaan Fakultas Geografi

Jl. Kaliurang, Sekip Utara, Yogyakarta 55281

Telp: (+62) 274-589595, Fax: (+62) 274-589595

Email: bpfg.geo@ugm.ac.id

\section{REMBUG PAGEBLUG}

Dampak, Respons dan Konsekuensi Pandemi Covid-19 dalam Dinamika Wilayah

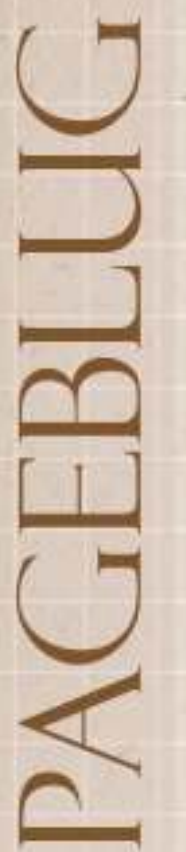

童

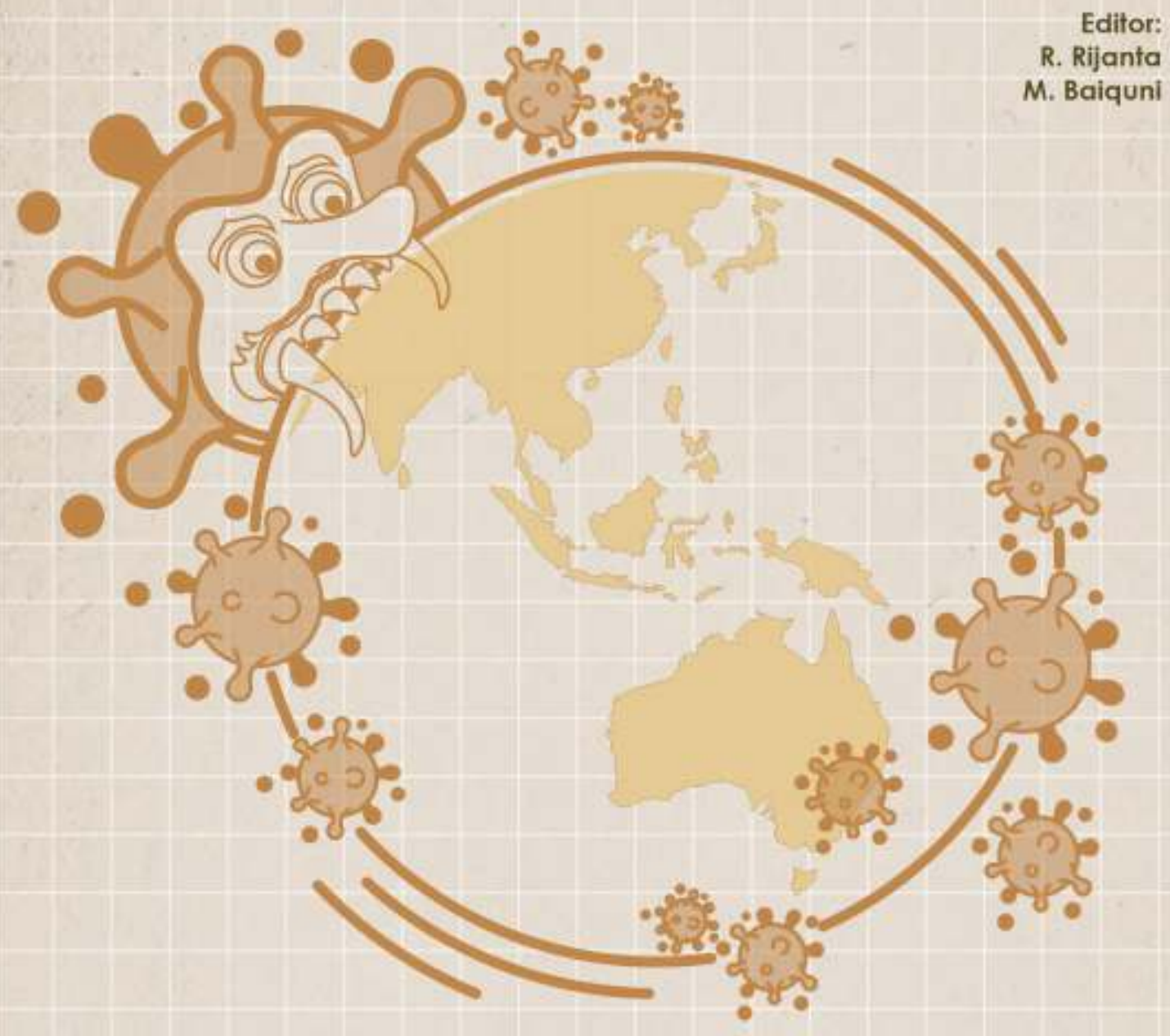

BADAN PENERBIT FAKULTAS GEOGRAFI UNIVERSITAS GADJAH MADA 


\section{Judul:}

Rembug Pageblug: Dampak, Respons dan Konsekuensi Pandemi Covid-19 dalam Dinamika Wilayah

\section{Editor:}

R. Rijanta

M. Baiquni

\section{Tata Letak:}

Rizki Adriadi Ghiffari

\section{Desain Sampul:}

Bayu Kusuma Adi

Cetakan Pertama, September 2020

\begin{tabular}{|c|c|}
\hline $\begin{array}{c}\text { ISBN 978-623-6527-12-2 } \\
||||||||||||||||||||||||||\end{array}$ & $\begin{array}{l}\text { Diterbitkan oleh: } \\
\text { Badan Penerbit Fakultas Geografi (BPFG) } \\
\text { Universitas Gadjah Mada } \\
\text { Yogyakarta, Indonesia } \\
\text { Telp: (+62) 274-589595, Fax: (+62) 274- } \\
\text { 589595 } \\
\text { E-mail: bpfg.geo@ugm.ac.id }\end{array}$ \\
\hline
\end{tabular}

(C) Hak Cipta dilindungi oleh undang - undang. Dilarang memperbanyak dalam bentuk apapun tanpa izin tertulis dari editor. Hak intelektual dalam buku ini milik penulis yang tercantum pada setiap bab. 


\section{Daftar Isi}

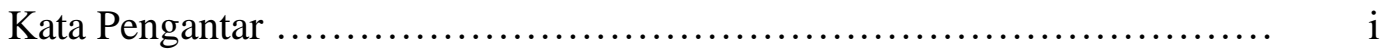

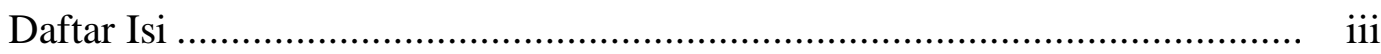

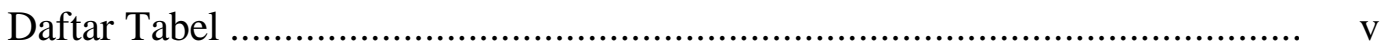

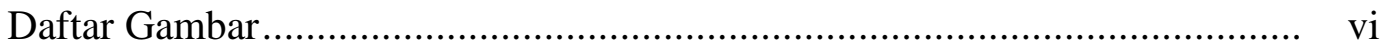

BAB 1

Editorial: Pageblug dalam Lintasan Ruang dan Waktu

R. Rijanta \& M. Baiquni ............................................. 1

BAB 2

Pandemi Covid-19 dalam Kacamata Pengelolaan Risiko Bencana

Estuningtyas Wulan Mei .......................................... 11

BAB 3

Kompleksitas Permasalahan Masyarakat Kota Pesisir: Covid-19, Bencana, dan Perubahan Iklim

Erlis Saputra

$\mathrm{BAB} 4$

Lingkungan dan COVID-19: Build Back Better from Home

Idea Wening Nurani, Sandy Budi Wibowo, Yuliana Rahmawati \& Rosalia

Desti Anggraeni

\section{BAB 5}

Daya Tahan Masyarakat Perkotaan di Era Pandemi Covid-19 dan Model

Taman Pangan Mandiri

Joko Christanto.

BAB 6

Urban Retrofitting sebagai Alternatif Konsep Penataan Ruang Perkotaan

Menghadapi Tatanan Kenormalan Baru Akibat Pandemi Covid-19

Rizki Adriadi Ghiffari.

BAB 7

Pemanfaatan Virtual Space pada Masa Pandemi Covid-19 di Perkotaan

Rini Rachmawati, Aditya Widya Pradipta, \& Ulfah Choirunnisa 


\section{BAB 8}

Konsekuensi Sosio-spasial, Dampak Produksi Pertanian dan Solidaritas Masyarakat Menghadapi Pandemi Covid-19

R. Rijanta

\section{BAB 9}

Adaptasi Masyarakat Kawasan Wisata Kalisuci: Perspektif Wali Murid SD Kalisuci pada Masa Pandemi Covid-19

Arry Retnowati

BAB 10

Respon Mahasiswa tehadap KBM Daring Selama Pandemi Covid-19 di Fakultas Geografi UGM

Andri Kurniawan, Moh. Syahrul Irfan Fahmi, Itsna Nur'aini \& Monalisa

Dyah Permatasari.

BAB 11

Working from Home (WfH): Kajian Ruang dan Waktu dari Perspektif Gender

Alia Fajarwati \& Sukamdi

BAB 12

School from Home Masa Covid-19 dalam Rumah Tangga: Praktik Kesetaraan atau Ketidaksetaraan Gender?

Surani Hasanati.

BAB 13

Aplikasi Analisis Keruangan dalam Kebijakan Menghadapi Covid-19

M. Isnaini Sadali \& Ersa Latifa Rosewidiadari.....

BAB 14

Dinamika Gagasan Penanganan Pandemi di Indonesia pada Masa Awal Penyebaran Covid-19: Sebuah Analisis Jejaring Diskursus

Hafidz Wibisono.

BAB 15

Epilog: Krisis Yang Terus Berlangsung dan Upaya Menemukan Solusi R. Rijanta \& M. Baiquni 